has shown is that a sufficiently determined and ingenious group of people can make a monkey of regulations at the national level intended to prevent the theft of ordinary people's goods and chattels. The affair is especially embarrassing for Britain, where the bank was a biggish player and where no fewer than four unconnected trials of people accused of the dishonest manipulation of financial institutions are simultaneously under way in the courts.

Those in the research and other professions inclined to view these happenings as irrelevancies should reflect on three matters. First, the funds spirited away often belong in part to them, through their investments in pension funds and with insurance companies. Second, the scope of the irregularities now apparently commonplace in the financial world invite comparison with those which the research profession is from time to time preoccupied. Third, the prospects that the management of our global village will be informed by the civility of which individual nations are proud are forced, by these events, to recede.

Banks are rightly regarded as pillars of the establishment. More to the point, they are engines of economic and technical change. The principle, first recognized in Italy in the fourteenth century, is that they undertake to look after funds belonging to one class of customers (depositors) and then lend the same funds to a second class of customers (borrowers). When it works well, the banking system is a means of pooling the resources of many people to finance projects beyond the resources of individuals. How many of those who bought James Watt's first steam engines, for example, would have been able to buy them out of their own pockets? But when the banking system works improperly, as in the case of BCCI, it can be a way of pouring people's wealth into projects that cannot succeed (which betokens bad judgement) or, sometimes, simply into chosen people's pockets (which is fraud).

Almost from the outset, the dangers of malpractice have been recognized. Most jurisdictions require that nationally registered banks should keep in a form equivalent to cash (government securities, for example, or deposits with the central bank) at least a fixed proportion of their outstanding loans (laughably, in the light of recent experience, called "assets" in the banking trade). In some places, banks are forbidden to trade in the securities of public companies from fear that over-close involvement with necessarily risky businesses may put depositors' funds in hazard. (One of the cases now being tried in Britain involves an allegation that a subsidiary of an important bank improperly concealed the purchase of a public company's stock so as to manipulate its price.) The great collapse of the savings and loan industry in the United States, likely to cost US taxpayers $\$ 500,000$ million eventually, has different roots; the lifting in the early 1980s of restrictions on how the banks could use their funds while leaving the public guarantee of deposits (up to $\$ 100,000$ ) intact invited a host of bankers to make "heads I win; tails you lose" gambles.

Can anything be done? BCCI seems to have escaped some of the rigours of regulation by moving its registered office from London to Luxembourg, and to have plugged some of the holes in its deteriorating balance sheet by persuading its principal shareholder, the ruler of Abu Dhabi, to put up extra funds. What proportion of the bank's supposed $£ 23,000$ million worth of assets is recoverable remains to be discovered, but there is a high chance that, yet again, more wealth will have vanished into thin air. It is by no means irrelevant that the total of the wealth spirited away in the past few years by the failure of banks and public companies is comparable with the sums of money required to solve major problems in the world - the burden of poor countries' debt, for example, and the cost of revitalizing the Soviet Union's economy (over which the heads of rich governments have been sucking their teeth this week in London).

The remedies are not tighter restrictions on what banks and other financial institutions are legally allowed to do, but closer and much more transparent scrutiny of what they get up to. The law requires that financial institutions should justify their conduct of affairs to their shareholders, but do they not also owe a similar duty to their depositors? And while it may be true that poor judgement by a banker is not the same as fraud, should not those whose judgement is consistently faulty be recognized as such more conspicuously than by the cancellation of their annual salary bonuses?

\section{Friends for France}

The French government is trying out random (as distinct from anonymous) peer review.

THE French ministry of education has hit on a novel way of assessing the quality of those who teach at French universities. In the past few week, several people outside France have been sent letters by the ministry's director of research and graduate studies asking for the names of those French scientists whom the respondents consider to be "first-class scientists", of research groups "that would compare favourably" with others elsewhere and of people who have made "any contribution to science on a broad scale". Many recipients of the questionnaire have been nonplussed by it, not least because answers cannot be obtained simply by checking boxes.

There will, of course, be general sympathy for the ministry's ambitions. The French university system is growing quickly, as is the usual difficulty of telling who is good and who less good. It also makes sense that administrations should seek advice on such questions from outside their own parishes. (The German MaxPlanck Gesellschaft has had great success with including scientists from overseas on its advisory councils.) But a general enquiry of the kind now put out is unlikely to provide the ministry of education with more than trouble. Some recipients of the circular will not answer, some will take endless quasi-judicial trouble and other will sing the praises of their chums. And what would happen if some French academics should set about soliciting responses of the third kind? 